\title{
An inhibitor of clot formation in cord plasma
}

Citation for published version (APA):

Kirchhof, B. R. J., Muller, A. D., \& Hemker, H. C. (1979). An inhibitor of clot formation in cord plasma. Thrombosis Research, 15(3/4), 389-403. https://doi.org/10.1016/0049-3848(79)90146-4

Document status and date:

Published: 01/01/1979

DOI:

10.1016/0049-3848(79)90146-4

Document Version:

Publisher's PDF, also known as Version of record

\section{Please check the document version of this publication:}

- A submitted manuscript is the version of the article upon submission and before peer-review. There can be important differences between the submitted version and the official published version of record.

People interested in the research are advised to contact the author for the final version of the publication, or visit the DOI to the publisher's website.

- The final author version and the galley proof are versions of the publication after peer review.

- The final published version features the final layout of the paper including the volume, issue and page numbers.

Link to publication

\footnotetext{
General rights rights.

- You may freely distribute the URL identifying the publication in the public portal. please follow below link for the End User Agreement:

www.umlib.nl/taverne-license

Take down policy

If you believe that this document breaches copyright please contact us at:

repository@maastrichtuniversity.nl

providing details and we will investigate your claim.
}

Copyright and moral rights for the publications made accessible in the public portal are retained by the authors and/or other copyright owners and it is a condition of accessing publications that users recognise and abide by the legal requirements associated with these

- Users may download and print one copy of any publication from the public portal for the purpose of private study or research.

- You may not further distribute the material or use it for any profit-making activity or commercial gain

If the publication is distributed under the terms of Article $25 \mathrm{fa}$ of the Dutch Copyright Act, indicated by the "Taverne" license above, 
THROMBOSIS RESEARCH $15 ; 389-403$

Pergamon Press Ltd.1979. Printed in Great Britain

AN INHIBITOR OF CLOT FORMATION IN CORD PLASMA

B.R.J.Kirchhof, A.D.Muller, H.C.Hemker

Department of Biochemistry, State University of Limburg, Maastricht, The Netherlands

(Received 25.9.1978; in revised form 8.3.1979

Accepted by Editor L. Vroman)

\section{ABSTRACT}

An inhibitor of the coagulation in cord plasma can be extracted by phosphotungstic acid or acetone. The way of action of this inhibitor is tested by means of synthetic chromogenic substrates, thrombin times, two-stage thrombin generation tests and thrombelastography. This inhibitor seems to act mainly on the behaviour of fibrin. The possibility cannot be excluded that the inhibitor also has a small effect on thrombin or thrombin generation. Some differences in the coagulation of adult and newborn plasma may be explained by this newborn inhibitor.

\section{INTRODUCTION}

The coagulation of newborn plasma differs in various respects from that of adult plasma. Thrombin times of newborn plasma are prolonged as compared with those of adult plasma (1). The concentrations of the vitamin $\mathrm{K}$-dependent factors and antithrombin III in newborn plasma are lower than those in adult plasma (2). The clots formed in newborn plasma are less compressible and more transparant than those in adult plasma at high ionic strength (3). In 1976, Van Doorm (4) concluded from thrombotest dilution curves and two-stage thrombin generation tests that cord plasma contains a thrombin inhibitor. He suggested a heparin-like action for this inhibitor. However, other investigators were not able to determine heparin or heparinoids in cord plasma $(5,6)$. Moreover, the question whether there is a fetal fibrinogen has not yet been answered (7). Froperties attributed to fetal fibrinogen might in fact be partly due to the 
presence of inhibitors.

In the present article we describe the attempts that were made to characterize the way of action of the inhibitor in cord plasma.

MATERIALS AND METHODS

Materials

Al1 plasmas used were prepared as described by Muller et al. (2). Thromboplastin was prepared from human brain according to the method of Owren and Aas (8). Thrombotest reagent was purchased from Nyegaard, Oslo, thrombin as Topostasine ${ }^{R}$ from Roche, Basel, heparin (sodium salt from porcine intestinal mucosa) and crystallized trypsin from Sigma, St.Louis. The chromogenic substrate Chromozym ${ }^{R}$ TH was a gift from Boehringer, Mannheim. All other chemicals were reagent grade.

Methods

1. Preparation of plasma fractions containing the inhibitor

Methanol/acetone precipitation and subsequent trypsin digestion were carried out as described by Engelberg et al.(9). Thrombin times were measured after each preparation step (acetone, methanol, methanol/acetone, methanol/acetone followed by trypsin digestion). Precipitation with phosphotungstic acid was effected by adding one volume of water and one volume of phosphotungstic acid $\left(10 \% \mathrm{Na}_{2} \mathrm{WO}_{2} \mathrm{w} / \mathrm{v}\right.$ in 0.67 $\mathrm{N}$ sulfuric acid) to two volumes of plasma. The supernatant was dialyzed against water at $4^{\circ} \mathrm{C}$ and freeze-dried.

2. Determination of inhibitor activity

The inhibitor activity was determined by the prolongation brought about in thrombin times, in the clotting times measured in a two-stage prothrombin assay, and in the parameters of the thrombelastogram. Thrombin times were measured by adding $0.05 \mathrm{ml}$ of a thrombin solution $(10 \mathrm{U} / \mathrm{ml})$ to a mixture of $0.1 \mathrm{ml}$ plasma and 0.1 $\mathrm{ml}$ buffer or inhibitor preparation, unless stated otherwise. Two-stage prothrombin assays were performed as described by Hemker et al.(10). However, $\mathrm{Al}(\mathrm{OH})_{3}$ adsorbed human adult or cord plasma was used instead of barium sulfate adsorbed bovine plasma. The $\mathrm{Al}(\mathrm{OH})_{3}$ adsorption was carried out twice with a final plasma concentration amounting to $1 \%$.

All solutions were prepared in Michaelis buffer. All tests were performed at $37^{\circ} \mathrm{C}$. The effect of heparin or the inhibitor on thrombin, generatea in hunan plasma by human factor $\mathrm{X}_{a}$ was measured using Chromozym ${ }^{R}$ TH as outlined earlier (i1). clot formation was observed by thrombelastography using a thrombelastograph I from Hellige, Germany. Instead of $0.3 \mathrm{ml}$ plasma only $0.28 \mathrm{ml}$ was used and 0.02 $\mathrm{m} 1$ buffer (one volume Michaelis buffer and nine volumes $0.9 \%$ NaCl), inhibitor 
solution and/or protamin sulfate was added.The solubility of the formed clot in acetic acid was tested as described by Duckert et al.(12).

RESULTS

\section{A. Partial fractionation}

Table I shows the thrombin times of mixtures of normal adult plasma and various plasma fractions or buffer.

\section{TABLE I}

The effects of various plasma fractions or buffer on the thrombin times of normal adult plasma

\begin{tabular}{|l|ccc|}
\hline $\begin{array}{l}\text { Precipitation } \\
\text { with }\end{array}$ & \multicolumn{3}{|c|}{$\begin{array}{c}\text { Addition of supernatant from } \\
\end{array}$} \\
adult plasma & newborn plasma & buffer time \\
time (sec) & time (sec) & time (sec) \\
\hline methanol & 13.4 & 14.1 & 11.4 \\
acetone & 15.8 & 58.6 & 11.4 \\
methanol/acetone & 11.2 & 11.1 & 11.1 \\
phosphotungstic acid & 12.4 & 60.0 & 12.4 \\
\hline
\end{tabular}

For the reaction $0.2 \mathrm{ml}$ normal adult plasma (fibrinogen content $3.7 \mathrm{~g} / 1$ ) was incubated for $60 \mathrm{~s}$ with $0.1 \mathrm{ml}$ plasma fraction or buffer.Clot formation was initiated by adding $0.5 \mathrm{ml}$ thrombin $(10 \mathrm{U} / \mathrm{ml})$. Means of 6 determinations .

A prolonged thrombin time was observed when the supernatant, obtained after precipitation with acetone or phosphotungstic acid, was added to normal adult plasma. However, the supernatants, obtained after precipitation with methanol or methanol/acetone (with or without subsequent trypsin digestion), had no effect on the thrombin times. All precipitates were without inhibitory activity. For the following experiments use was made of the freezedried supernatant obtained after phosphotungstic acid precipitation and dialysis against water of a pool of 80 cord plasma samples of normal newborns. A preliminary characterization of the freeze-dried powder from $1 \mathrm{~m} 1 \mathrm{plasma}$ gave the following components: $0.3 \mathrm{mg}$ protein (Lowry method), $0.06 \mathrm{mg}$ total saccharides (calculated from total hexose) and less than $5 \%$ phospholipids (calculated as lipid phosphorus).

B. Mode of action of the inhibitor

1. Effect on thrombin times

Fig. 1 shows thrombin times of normal adult plasma as a function of inhibitor preparation added, as compared to the effect of adding heparin solution. 


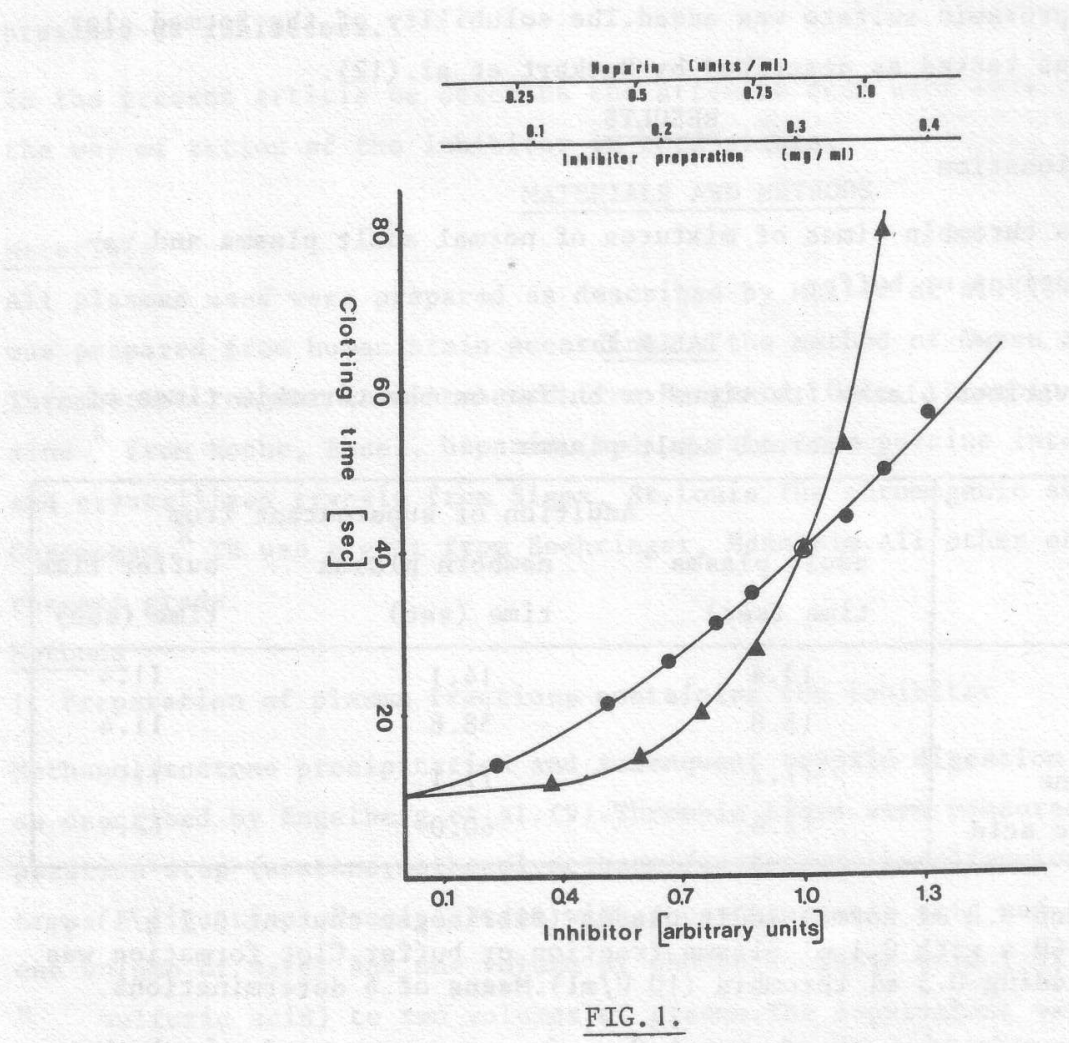

Thrombin times of mixtures of $0.1 \mathrm{ml}$ normal adult plasma and $0.1 \mathrm{~m} 1$ of inhibitor (- ) or heparin solution ( $-\Delta$ ). (both in Michaelis buffer). After one minute incubation at $37^{\circ} \mathrm{C} 0.05 \mathrm{ml}$ thrombin $(10 \mathrm{U} / \mathrm{ml})$ was added. One arbitrary unit was defined as the concentration of inhibitor preparation or heparin which prolonged the thrombin time to 40 seconds.

In the same range of clotting times the effect of heparin differed from that of inhibitor. The results summarized in table II were obtained with a $1 / 5$ dilution of $\mathrm{Al}(\mathrm{OH})_{3}$ adsorbed adult or newborn normal plasma, as a fibrinogen source. Clot formation was started with various thrombin concentrations. The difference in the effect of the inhibitor on newborn and on adult material was also found using whole plasma or purified fibrinogensinstead of $\mathrm{Al}(\mathrm{OH})_{3}$ adsorbed plasma (not shown here). The difference was more pronounced in the adsorbed plasma.

2. Effect on the amidolytic activity of thrombin

If the inhibitor possessed heparin-like activity in preparations containing antithrombin III, there should be an inhibitory effect on the amidolytic activity of thrombin and factor $x_{a}$ by acceleration of the antithrombin III mediated thrombin and factor $\mathrm{X}_{\mathrm{a}}$ inactivation.Therefore, the amidolytic activity was measured using synthetic chromogenic substrates. In experiments with purified 
sources, no effect was found on the amidolysis of S 2222 (substrate specific for factor $x_{a}$ ) or $S 2238$ (substrate specific for thrombin). The inhibition of the amidolytic activity of thrombin by antithrombin III was not accelerated by the inhibitor when the reaction was carried out in human whole plasma with luman factor $\mathrm{X}_{\mathrm{a}}$ as prothrombin activator.

\section{TABLE II}

Thrombin times of $\mathrm{Al}(\mathrm{OH}) 3^{\text {-adsorbed }}$ plasma (seconds).

\begin{tabular}{|c|cc|cr|}
\hline $\begin{array}{l}\text { Thrombin } \\
(\mathrm{U} / \mathrm{m} 1)\end{array}$ & $\begin{array}{l}\mathrm{Al}(\mathrm{OH})_{3} \text {-adsorbed } \\
\text { + buffer }\end{array}$ & $\begin{array}{r}\text { adult plasma } \\
\text { +inhibitor }\end{array}$ & $\begin{array}{l}\mathrm{Al}(\mathrm{OH}) \\
\text { + buffer }\end{array}$ & $\begin{array}{r}\text {-adsorbed newborn plasma } \\
\text { +inhibitor }\end{array}$ \\
\hline 5 & 18.4 & 33.9 & 37.1 & 300 \\
10 & 12.8 & 24.1 & 17.9 & 124.7 \\
25 & 8.2 & 21.0 & 12.8 & 54.3 \\
\hline
\end{tabular}

For the reaction $0.18 \mathrm{ml} \mathrm{Al(OH})_{3}$-adsorbed adult- or newborn plasma was incubated for $60 \mathrm{~s}$ with $0.02 \mathrm{ml}$ inhibitor solution $(0.125 \mathrm{mg} / \mathrm{ml})$ or buffer.Clot formation was initiated by adding $0.05 \mathrm{ml}$ thrombin solution. Means of 6 determinations.

Fig. 2 demonstrates that in the presence of normal plasma the amidolytic activity of thrombin slowly decreases an effect for which antithrombin III can be held responsible. This decay was not affected by the inhibitor using about three times the amount $(1.2 \mathrm{mg} / \mathrm{ml})$ found in a newborn pool. Addition of 0.5 units heparin/m1 caused a rapid acceleration of the antithrombin III action.

3. Effect on thrombin generation

In the two-stage method the measured clotting times depend on the thrombin concentration generated in the first incubation mixture and on the fibrinogen source used in the second one.The thrombin concentration is the result of the thrombin generating enzyme system and the thrombin inactivation actions (in whole plasma mostly due to antithrombin III). Figs. 3 and 4 give the results of such two-stage methods.For the results shown in these figures,thrombin was generated in adult plasma (fig.3) or newborn plasma (fig.4), and the effect of the incubation mixture was determined using $\mathrm{Al}(\mathrm{OH}) 3^{\text {-adsorbed }}$ cord or adult plasma. To each incubation mixture $0.1 \mathrm{ml}$ of inhibitor solution $(0.4$ mg crude preparation /ml of Michaelis buffer) was added.

When normal adult plasma was added to the incubation mixture and the assay was performed in either $\mathrm{Al}(\mathrm{OH})_{3}$ adsorbed newborn or adult plasma, the plots 


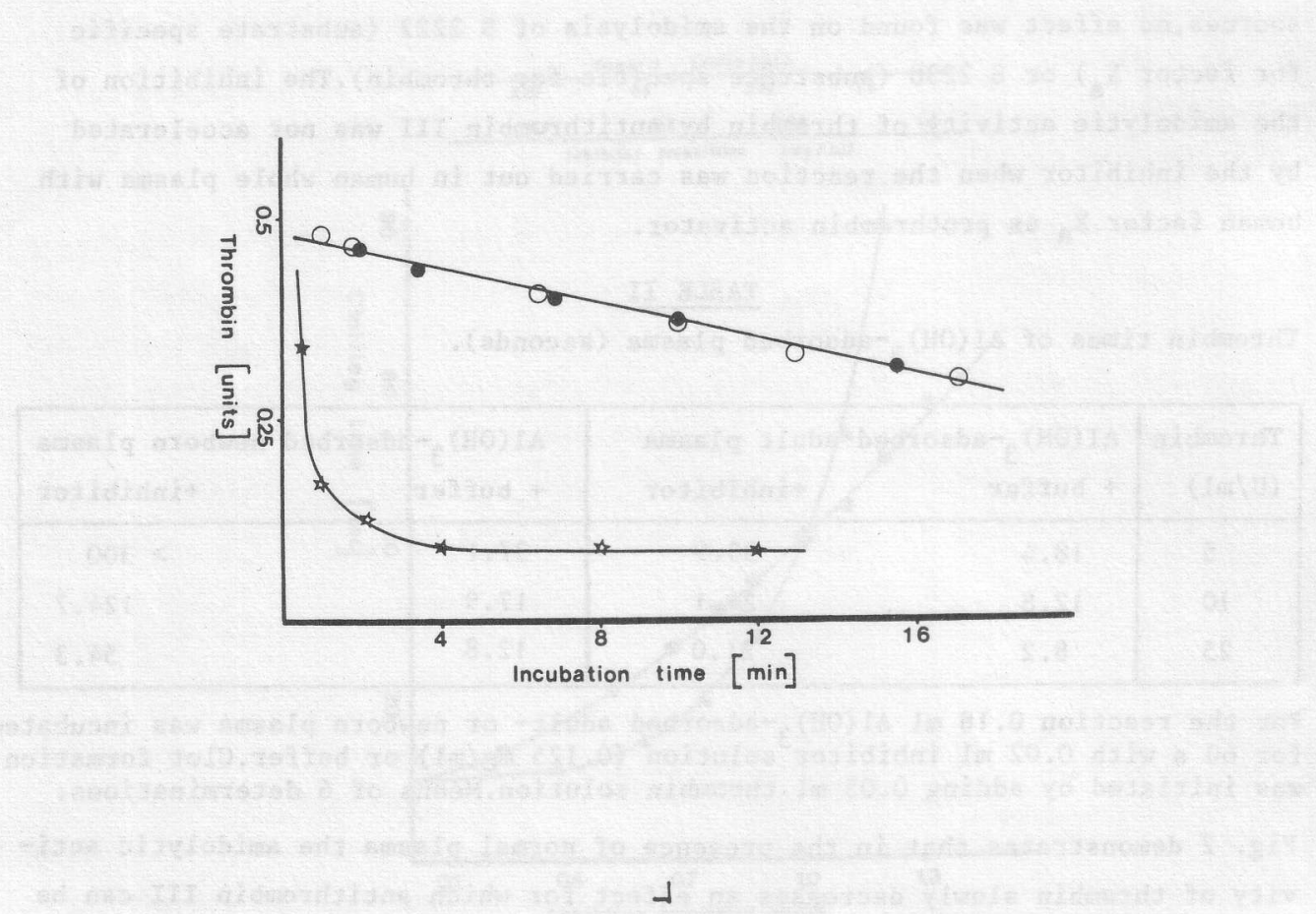

FIG. 2 .

The amidolytic acitivity of thrombin as a function of its inhibition by antithrombin III. For the reaction $2 \mu 1$ normal adult plasma, $2 \mu 1$ phospholipids, $40 \mu 10.1 \mathrm{M} \mathrm{CaCl}_{2}, 2 \mu 1$ human factor $\mathrm{X}_{\mathrm{a}}$ preparation and $300 \mathrm{Hl}$ imidazol buffer were incubated for two minutes. To the incubation mixture $2 \mu 1$ buffer (o- o), inhibitor solution (- -$)(1.2 \mathrm{mg} / \mathrm{ml})$ or heparin solution ( $\star-\star)(0.5$ units/m1) was added. After various second incubation times $50 \mu 1$ substrate was added and the release of p-nitroanilide was measured at $391 \mathrm{~nm}$. The thrombin concentration was calculated from a standard curve.

of the thrombin concentration versus the incubation time were the same. Addition of inhibitor to the thrombin generating mixture led to a decrease of the maximum thrombin concentration and to a more rapid decrease of thrombin concentration with increasing incubation time. There was no difference using $\mathrm{Al}(\mathrm{OH})_{3}$ adsorbed newborn or $\mathrm{Al}(\mathrm{OH})_{3}$-adsorbed adult plasma for the second incubation, if thrombin was calculated from the according standard curves. However, when newborn plasma was added to the incubation mixture, addition of inhibitor preparation led to different curves tested on adult and newborn $\mathrm{Al}(\mathrm{OH})_{3}$ adsorbed plasma (fig. 4). Maximum thrombin concentrations were observed at an incubation time of $2.5 \mathrm{~min}$. Further increase of incubation time was accompanied by a more rapid decrease in thrombin concentration when the assay was performed 


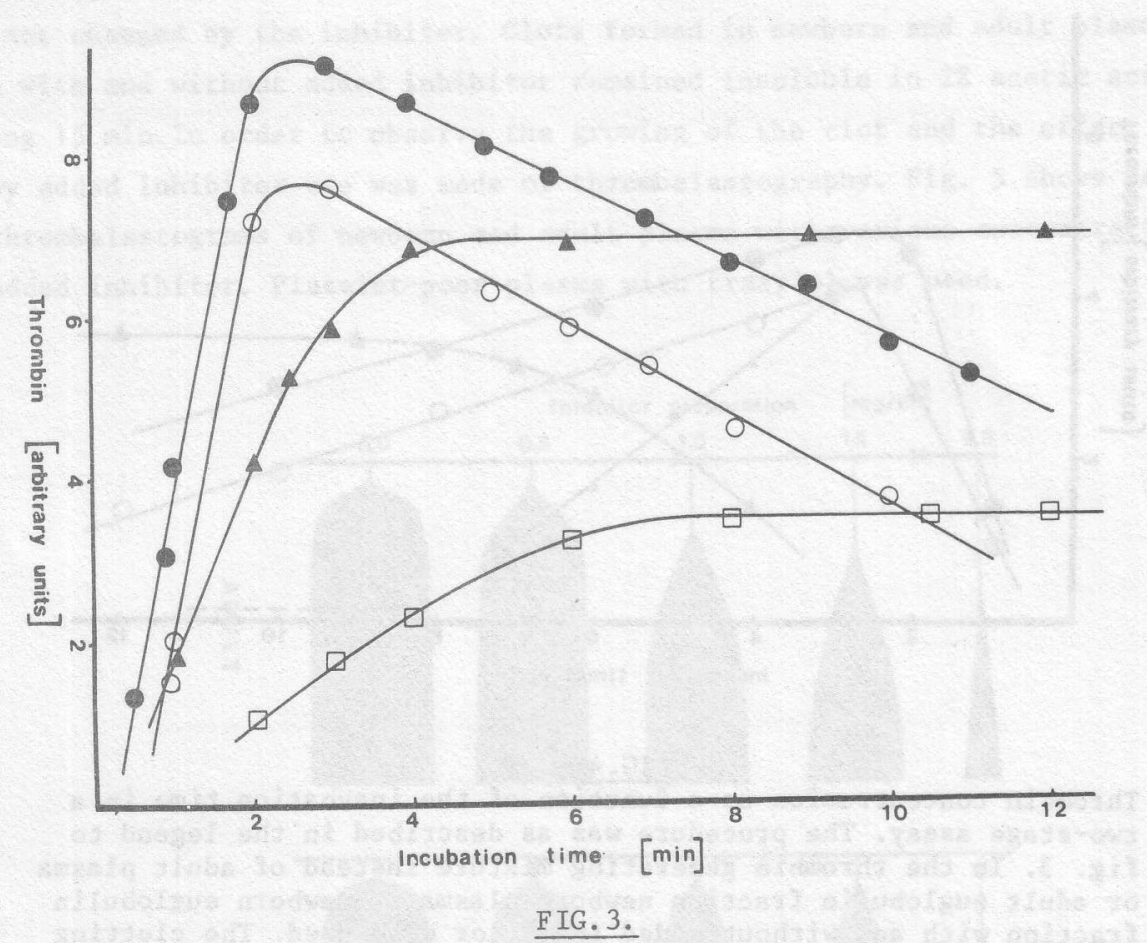

Thrombin concentration as a function of the incubation time in a twostage assay. Clot formation in $\mathrm{Al}(\mathrm{OH})_{3}$ adsorbed newborn plasma was used as an indirect measure of the actual amount of thrombin, generated in whole or in euglobulin fraction plasma from adults with or without added inhibitor. The thrombin generating mixture consisted of $1.7 \mathrm{~m} 1$ Michaelis buffer, $0.1 \mathrm{ml}$ plasma, $0.1 \mathrm{ml}$ inhibitor solution $(0.4 \mathrm{mg} / \mathrm{ml})$ or buffer and $0.1 \mathrm{ml}$ thromboplastin. Thrombin generation was started with $1 \mathrm{ml} 1 / 30 \mathrm{M} \mathrm{CaCl}_{2}$. After various incubation times, $0.1 \mathrm{ml}$ of the incubation mixture was added to $0.1 \mathrm{ml} \mathrm{Al(OH})_{3}$ adsorbed plasma diluted $1 / 5$, and the clotting time was recorded. The thrombin concentration was calculated from a standard curve.

- - whole plasma; o-o, whole plasma with added inhibitor;

- $A$, euglobulin fraction; $\square-\square$; euglobulin fraction with added inhibitor.

in newborn $\mathrm{Al}(\mathrm{OH})_{3}$-adsorbed plasma compared to the assay performed in adult A. $(\mathrm{OH}) 3^{\text {-adsorbed }}$ plasma. The standard curves were the same as for the assays with adult plasma in the thrombin generation mixtures. Maximum thrombin concentration was less in newborn plasma because normal newborn plasma has about $50 \%$ of the prothrombin concentration found in adult plasma and because the inhibitor is present in the newborn pool. Similar results were obtained using purified fibrinogen instead of $\mathrm{Al}(\mathrm{OH})_{3}$ adsorbed plasma in the second stage. In order to find out to which extent the effect of the added inhibitor belonged to antithrombin III action, the euglobulin fractions of either adult or newborn plasma were used for the thrombin generating mixture instead of whole plasma. As shown 


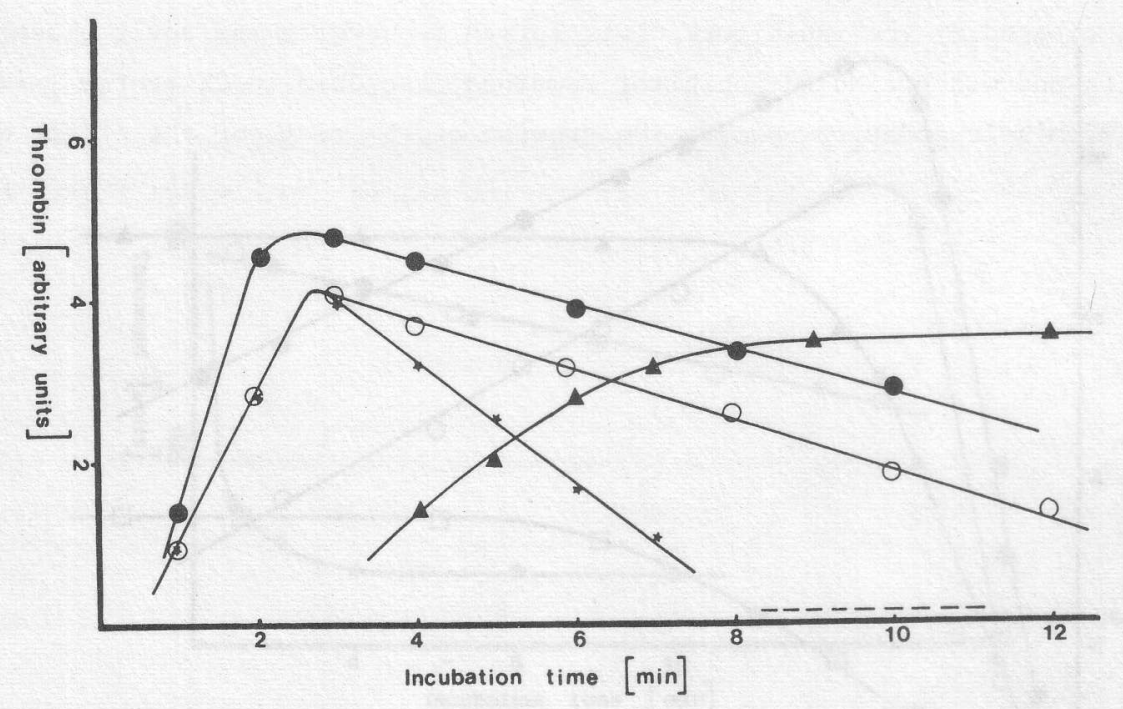

FIG. 4.

Thrombin concentration as a function of the incubation time in a two-stage assay. The procedure was as described in the legend to fig. 3. In the thrombin generating mixture instead of adult plasma or adult euglobulin fraction newborn plasma or newborn euglobulin fraction with and without added inhibitor were used. The clotting activity of the thrombin generating mixture was measured in newborn $\mathrm{Al}(\mathrm{OH})_{3}$ adsorbed plasma and in the case of newborn whole plasma with additional inhibitor also in adult $\mathrm{Al}(\mathrm{OH})_{3}$ adsorbed plasma. - - whole plasma; o - o, whole plasma with inhibitor assayed in adult $\mathrm{Al}(\mathrm{OH})_{3}$-adsorbed plasma; * - *, whole plasma with inhibitor assayed in newborn $\mathrm{Al}(\mathrm{OH}) 3^{\text {-adsorbed plasma; }}$ -..-, euglobulin fractions with inhibitor.

in fig. 3 for adult and in fig. 4 for newborn euglobulin fractions in the thrombin generating mixtures, an increase in the incubation time gave rise to an increase in thrombin concentrations, that was diminuated by the addition of inhibitor to the incubation mixture. Inactivation of thrombin was not observed neither in euglobulin fractions without additional inhibitor nor in fractions with additional inhibitor. Euglobulin fractions of newborn plasma showed no measurable thrombin after addition of inhibitor. The inhibition does not vanish in euglobulin fractions, so antithrombin 3 is not necessary. The maximum thrombin concentrations were less in assays with euglobulin fractions than those in assays with whole plasma because of a loss of prothrombin during fractionation.

4. Effect on the clot quality Usually clots formed by addition of $\mathrm{CaCl}_{2}$ and thrombin do not dissolve in $2 \%$ acetic acid within 15 min because of the action of factor XIII. This behaviour 
was not changed by the inhibitor. Clots formed in newborn and adult plasma both with and without added inhibitor remained insoluble in $2 \%$ acetic acid during $15 \mathrm{~min}$. In order to observe the growing of the clot and the effect on it by added inhibitor use was made of thrombelastography. Fig. 5 shows series of thrombelastograms of newborn and adult plasma with various concentrations of added inhibitor. Platelet-poor plasma with trasylol was used.

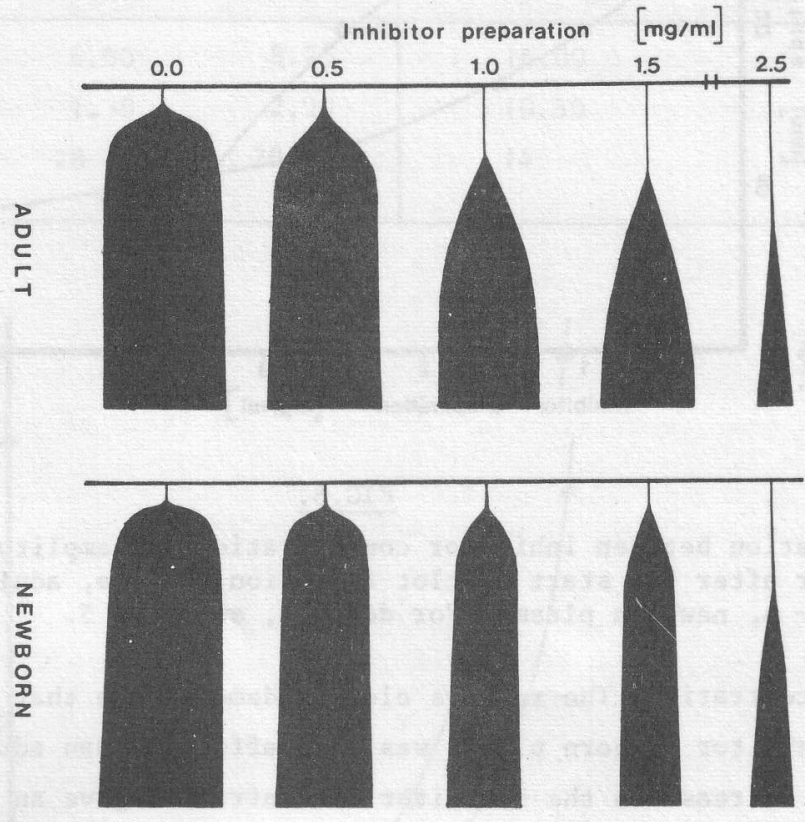

FIG.5.

Thrombelastograms of newborn and adult plasma with various concentrations of added inhibitor. The mixture used consisted of $0.28 \mathrm{ml}$ plas$\mathrm{ma}, 0.02 \mathrm{ml}$ buffer or inhibitor solution and $0.06 \mathrm{ml}$ of a $1.29 \% \mathrm{CaCl}_{2}$ solution. The inhibitor solution was prepared in buffered saline (one volume Michaelis buffer and nine volumes $0.9 \% \mathrm{NaC} 1$ ).

Therefore, the measurements were not affected by thrombacytes or fibrirolytic activities. The effect of the inhibitor added to newborn plasma differed from the effect observed when inhibitor was added to adult plasma. The effect of inhibitor on the amplitude measured was less in adult plasma than in newborn plasma. Large differences were observed for the maximum amplitudes, which at the same time depended on the inhibitor concentration. The maximum amplitudes did not change over a period of 18 hours. Big. 6 shows the amplitude measured one hour after clot formation started $\left(a_{1 h}\right)$, as function of 


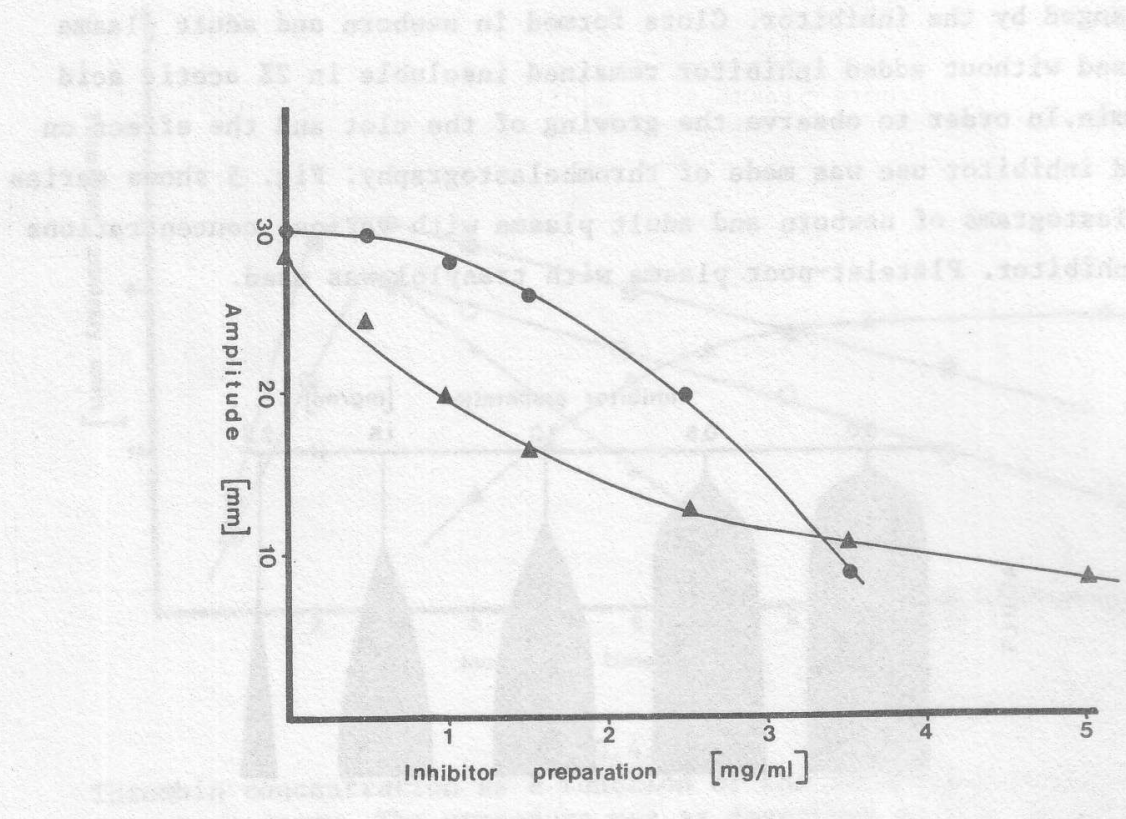

FIG.6.

Relation between inhibitor concentration and amplitudes reached one hour after the start of clot formation. - - adult plasma; $\Delta-\Delta$, newborn plasma. For details, see fig. 5.

inhibitor concentration. The results clearly demonstrate that at 10 concentration of inhibitor newborn plasma was more affected than adult plasma. Fig. 7 shows that an increase in the inhibitor concentration gave an increase in the $r$ and $k_{10}$-time. It should be mentioned that an increase in inhibitor concentration produced an increase in both $\mathrm{r}^{-}$and $\mathrm{k}_{10^{-t i m e}}$. Considering inhibitor concentrations similar to those in the clotting assays (1ess than $2 \mathrm{mg} / \mathrm{ml}$ in the present system) it is clear that there was only a small difference between adult and newborn plasma for the $r$ - and $k_{10}$-times. On the other hand, the effect of the inhibitor concentration on $\mathrm{r}-$ and $\mathrm{k}_{10^{-t i m e s}}$ was more pronounced in adult plasma than in newborn plasma. The $\mathrm{r}$ - and $\mathrm{k}_{10}$-times were prolonged by the addition of protamin-sulfate, both for newborn and adult plasma. The $a_{1 h}$ value was virtually not affected by the addition of protamin-sulfate. Addition of both protamin-sulfate and inhibitor to newborn plasma produced a lower $k_{10}$-time than addition of inhibitor alone (compare table III). R-time and $a_{1 h}$ hardly changed. This indicates that the expected increase of the $r$-time by protamin-sulfate did not occur. 


\section{TABLE III}

Thrombelastography of newborn plasma with addition of protamin-sulfate. Means of 4 determinations.

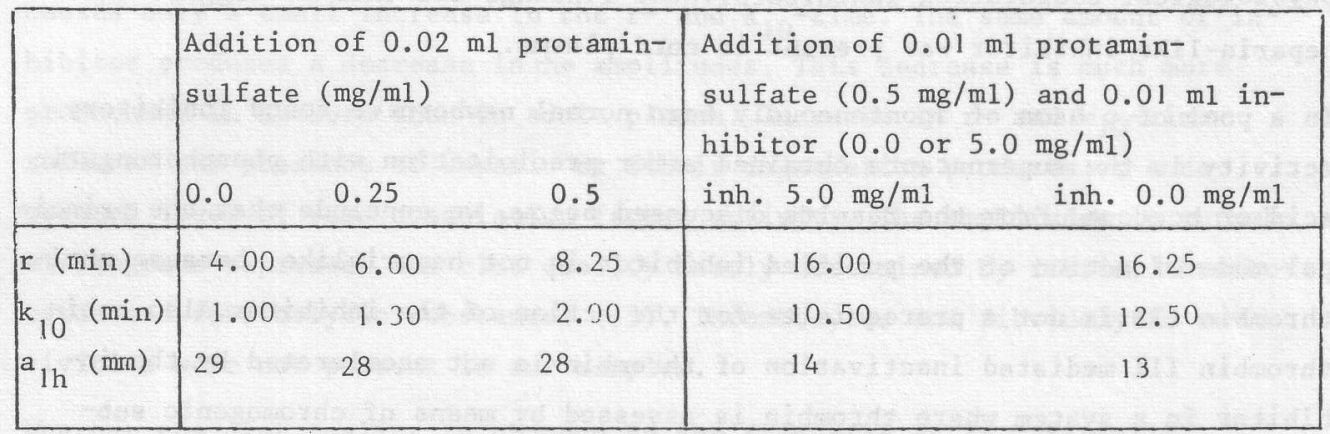

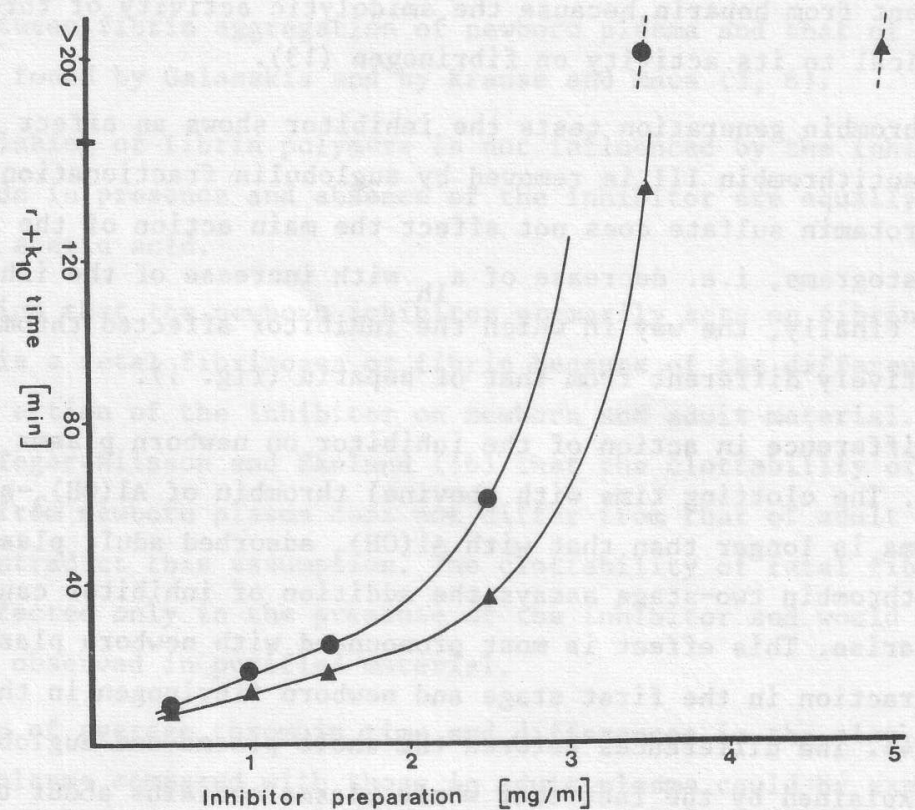

FIG. 7.

Thrombelastography of adult and newborn plasma. Relation between inhibitor concentration and the sum of the times, in which the clot formation after addition of $\mathrm{CaCl}_{2}$, started ( $r$-time) and the time in which the amplitude reached $10 \mathrm{~mm}$ after the start of clot formation

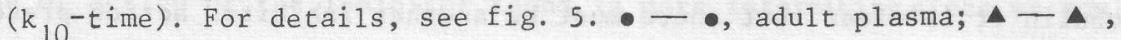
newborn plasma.

\section{DISCUSSION}

Van Doorm and Muller et al. $(2,4)$ found an inhibitor of the coagulation in 
about $2 / 3$ of all spontaneously born normal newborns. In two-stage prothrombin assays antithrombin III increased this inhibition and protamin-sulfate decreas. ed it. This could not be explained by differences in the concentrations of known physiological coagulation intibitors. These findings led them to suggest that a heparin-like inhibitor was present in cord plasma.

In a pool of plasma of spontaneously born normal newbornswe found inhibitory activity in the supernatants obtained after precipitation with phosphotungstic acid or acetone. From the results discussed below, we conclude that the principal mode of action of the purified inhibitor is not heparinlike, because antithrombin III is not a prerequisite for the action of the inhibitor.Also antithrombin III mediated inactivation of thrombin is not accelerated by the inhibitor in a system where thrombin is assessed by means of chromogenic substrate (fig. 2). This does not exclude that the inhibitor affects thrombin in a way different from heparin,because the amidolytic activity of thrombin needs not be identical to its activity on fibrinogen (13).

Further in thrombin generation tests the inhibitor shows an effect that persisted when antithrombin III is removed by euglobulin fractionation (figs. 3 and 4) and protamin sulfate does not affect the main action of the inhibitor in thrombelastograms, i.e. decrease of $a_{1 h}$ with increase of the inhibitor (table III). Finally, the way in which the inhibitor affected thrombin times was quantitatively different from that of heparin (fig. 1).

There is a difference in action of the inhibitor on newborn plasma and on adult plasma. The clotting time with (bovine) thrombin of $\mathrm{Al}(\mathrm{OH})_{3}$-adsorbed newborn plasma is longer than that with $\mathrm{Al}(\mathrm{OH})_{3}$ adsorbed adult plasma (table III). In prothrombin two-stage assays the addition of inhibitor causes less thrombin to arise. This effect is most pronounced with newborn plasma or its euglobulin fraction in the first stage and newborn fibrinogen in the second stage ( $\mathrm{fig} .4$ ). The differences between the whole plasma and euglobulin curves are explained by the fact that whole plasma contains about twice the amount of prothrombin as well as antithrombin III. The effect of the inhibitor on the experiment with whole plasma can be attributed to underestimation of the amount of thrombin generated because of the action of the inhibitor on fibrin formation. Yet when comparing the effect on whole plasma and euglobulin it is clear that there must be another inhibitor action present too, because in the euglobulin experiment the inhibition observed is much more pronounced. The same holds for the experiment shown in fig. 4. This effect in thrombin generation remains to be investigated, it is much less pronounced than the effect on fibrin formation. 
The conclusion that the inhibitor acts on fibrin formation is supported by the results of thrombelastography. The inhibitor affects both $\mathrm{r}-$ and $\mathrm{k}_{10^{-}}$ time as well as the amplitudes. Addition of reasonable amounts of inhibitor causes only a small increase in the $r-$ and $k_{10}$-time. The same amount of inhibitor produces a decrease in the amplitudes. This decrease is much more pronounced in newborn than in adult plasma. Increase in $r-$ and $k_{10}$ time reflects the presence of heparin or fibrin degradation products or a decreased level of some coagulation factor activity. The amplitudes in thrombelastograms represent the clot quality mostly determined by flbrin, thrombocytes and fibrinolytic substances (15). Thrombocytes and fibrinolytic activities were not present in our samples.

Whether the clot quality is changed by the formation of an "abnormal" fibrin or by an "abnormal" fibrin aggregation cannot be ascertained. Differences between fibrin aggregation of newborn piasma and that of adult plasma were found by Galanakis and by Krause and Maus $(3,6)$. The cross-linking of fibrin polymers is not influenced by the inhibitor, as clots made in presence and absence of the inhibitor are equally unsoluble in urea and acetic acid.

Our assumption that the newborn inhibitor premarily acts on fibrin includes that there is a fetal fibrinogen or fibrin because of the differences between the action of the inhibitor on newborn and adult material. The finding of Teger-Nilsson and Ekelund (16) that the clottability of purified fibrinogen from newborn plasma does not differ from that of adult plasma does not contradict this assumption. The clottability of fetal fibrinogen could be affected only in the presence of the inhibitor and would therefore not be observed in purified material.

Prolongation of average thrombin time and differences in the clot quality in newborn plasma compared with those in adult plasma could be explained by the action of the inhibitor and the presence of a fetal fibrinogen. Apart from that the concentrations of the normal procoagulant and anticoagulant factors are not the same in the adult and in the newborn (2), there is also a small as yet unexplained inhibiting effect on thrombin generation. The mode of action of the inhibitor found is more interesting since we could show that the level of inhibitor in cord plasma has a positive relation to the maturity of the newborn (birth weight, duration of pregnancy) and the way of delivery with a maximum after vaginal operation and a minimum after caesarean section (17). Investigations to characterize the mode of action 
of the inhibitor using purified newborn and adult fibrinogen and thrombin by means of gel- and immunoelectrophoresis are at work.

\section{ACKNOWLEDGEMENT}

We are grateful to Dr.M.Hoheisel and Dr.L.Keefer (Evangelisches Krankenhaus, Köln, GËR) for the preparation of the blood samples. Financial support was obtained from the Deutsche Forschungsgemeinschaft.

\section{REFERENCES}

1. ATAC, A., SPIELVOGEL, A.R., HOROWITZ, H.I. The prolonged thrombin clotting time in newborn. Coagulation 4, 41-46, 1971.

2. MULLER, A.D., VAN DOORM, J.M., HEMKER, H.C. Heparin-like inhibitor in normal newborn. Nature 267, 793-806, 1976.

3. GALANAKIS,D.K., MOSESSON, M.W. Evaluation of the role of in vivo proteolysis (fibrinogenolysis) in prolonging the thrombin time of human umbilical cord fibrinogen. Blood 48, 109-118, 1976.

4. VAN DOORM, J.M. De zogenaamde vitamine K deficiëntie van de pasgeborene. Ph.D.-thesis, Groningen, The Netherlands, 1976.

5. VON FELTEN, A., STRAUB, P.W. Coagulation studies of cord blood, with special reference to fetal fibrinogen. Thrombos.Diathes.haemorrh. 22, 273-280, 1969.

6. KRAUSE, W.H., MAUS, W. Untersuchungen zur Fibrinogen-Fibrin Umwandlung in Nabelvenenblut. Med. We1t 26, 2172-2174, 1975.

7. Krantz, S.,LOBER, M. UHersicht: Angeborene und erworbene Varianten des P1asmafibrinogens. Folia Haemato1. Leipzig 103, 793-806, 1976.

8. OWREN, P.A., AAS, K. The control of dicoumarol therapy and the quantitative determination of prothrombin and proconvertin. Scand.J.Clin. Invest. 3, 201-208, 1951 .

9. ENGELBERG, H., DUDLEY, A., FREEMEN, L. An improved method for the determination of plasma heparin. J.Lab.Clin.Med. 46, 653-656, 1955.

10. HEMKER, H.C., HEMKER, P.W. , TORREN, K. v.d. , DEV ILEE, P. P. , HERMENS, W. Th. , LOEL IGER, E.A. The evaluation of the two-stage prothrombin assay. Thrombos.Diathes. haemorrh. 25, 545-554, 1971.

11. KIRCHHOF, B.R.J., VERMEER, C., HEMKER, H.C. The determination of prothrombin using synthetic chromogenic substrates, choice of a suitable activator. Thrombos.Res. Accepted for publication. 1978.

12. DUCKERT,F., JUNG, E., SCHMERL ING,D.M. A hitherto undescribed congenital haemorrhagic diathesis, probably due to a fibrin stabilizing factor deficiency. Thrombos.Diathes.haemorrh. 5, 179-184, 1960. 
13. ØDEGAARD, O.R.,LIE, M. The use of chromogenic substrates for studies of coagulation inhibitors. Haemostasis 7, 121-126, 1978.

14. SWART,A.C.W., KLAASSEN, B.H.M., BLOYS-VAN TRESLONG DE GROOT, C.H.R., HEMKER, H.C. The adsorption of blood coagulation factors II,VII, IX, and X from human plasma to aluminum hydroxide.Thrombos.Diathes.haemorrh. 27, 490-501, 1972.

15. HARTERT,H. Thrombelastography. In "Thrombosis and Bleeding Disorders; Theory and Methods". Ed.N.U.Bang et al. Georg Thieme Verlag, Stuttgart, GFR. $70-77,1971$.

16. TEGER-NILSSON,A.C., EKELUND, H. Fibrinogen to fibrin transformation in umbilical blood and purified neonatal fibrinogen. Thrombos. Res. 5, 601-612, 1974. 
13. ØDEGAARD, O.R.,LIE,M. The use of chromogenic substrates for studies of coagulation inhibitors. Haemostasis 7, 121-126, 1978.

14. SWART, A.C.W., KLAASSEN, B. H.M., BLOYS-VAN TRESLONG DE GROOT, C.H.R., HEMKER, H.C. The adsorption of blood coagulation factors II, VII, IX, and X from human plasma to aluminum hydroxide. Thrombos.Diathes.haemorrh. 27, 490-501, 1972.

15. HARTERT,H. Thrombelastography. In "Thrombosis and Bleeding Disorders; Theory and Methods". Ed.N.U.Bang et al. Georg Thieme Verlag, Stuttgart, GFR. 70-77, 1971 .

16. TEGER-NILSSON,A.C., EKELUND, H. Fibrinogen to fibrin transformation in umbilical blood and purified neonatal fibrinogen. Thrombos.Res. 5, 601-612, 1974. 